\title{
硫化水素気化分離/同位体希勫/誘導結合プラズマ質量分析法 による鋼中の微量硫黄の定量
}

\author{
中 啓 ${ }^{\circledR *}$, 蔵保 浩文*, 馬 利 ${ }^{* *}$, 中原 武利 ${ }^{* * *}$
}

\section{Determination of trace amounts of sulfur in iron and steel by isotope dilution ICP-MS with a hydrogen sulfide evolution technique}

\author{
Hirohito Naka, Hirohumi Kurayasu ${ }^{*}, \mathrm{Li} \mathrm{MA}^{* *}$ and Taketoshi Nakahara ${ }^{* * *}$
}

${ }^{*}$ Sumitomo Metal Technology, Inc., 1-8, Fuso-cho, Amagasaki-shi, Hyogo 660-0891
${ }^{* *}$ Beijing General Research Institute for Non ferrous Metals, No. 2, Xinjiekou Wai St., Beijing, China
100088; Present address: Shimadzu Scientific Instruments \& Equipments Center, 5F, INSTEC
Commercial Bldg, B-19 Beisanhuanzhong Road, Xicheng District, Beijing, China 100029
*** Department of Applied Chemistry, Osaka Prefecture University, 1-1, Gakuen-cho, Sakai-shi, Osaka
599-8531

(Received 4 November 1997, Accepted 14 January 1998)

\begin{abstract}
A method for the determination of trace amounts of sulfur in high-purity iron by isotope dilution ICP-MS with a hydrogen sulfide evolution technique was established. Hydrogen sulfide evolved by the distillation of sample solutions was collected into sampling bags, and then was introduced directly into the ICP mass spectrometer. The effect of the distillation temperature and Ar carrier gas-flow rate on the distillation time was studied. Hydrogen sulfide was evaporated almost completely for about $20 \mathrm{~min}$ of distillation when a distillation temperature of $250^{\circ} \mathrm{C}$ and an Ar carrier gas flow rate of $100 \mathrm{ml}$ $\min ^{-1}$ were selected as the optimized distillation conditions. Optimization of the nebulizer gas-flow rate, $\mathrm{rf}$ power and sample gas-flow rate was accomplished by studying the effect of these three parameters on the intensity ratio of ${ }^{34} \mathrm{~S}^{+}$to ${ }^{32} \mathrm{~S}^{+}$and background intensity of ${ }^{32} \mathrm{~S}^{+}$and ${ }^{34} \mathrm{~S}^{+}$. The intensity ratios and backgound intensity reached more stable and lower levels respectively, when a nebulizer gas-flow rate of $0.881 \mathrm{~min}^{-1}$, an $\mathrm{rf}$ power of $1350 \mathrm{~W}$ and a sample gas-flow rate of $30 \mathrm{ml} \mathrm{min}^{-1}$ were selected as the optimum operating conditions. The proposed method was successfully applied to the determination of trace amounts of sulfur in Japan Iron and Steel Certified Reference Materials and a high-purity iron sample. The $\%$ RSD of $2.6 \%$ was achieved at a sulfur concentration of $2 \mu \mathrm{g} \mathrm{g}^{-1}$.
\end{abstract}

Keywords : sulfur determination; high-purity iron; ICP-MS; isotope dilution; hydrogen sulfide evolution; trace analysis.

*住友金属テクノロジー(株): 660-0891 兵庫県尼崎市扶桑町 1-8

** 北京有色金属研究総院: 100088 北京市新街口外大街 2 号 501 室; 現在, 北京島津科学儀器中心: 100029 北京市西 城区北三環中路乙 19 号 INSTEC 商業大厦 5 楼

*** 大阪府立大学工学部応用化学科: 599-8531 大阪府堺市学園町 1-1 


\section{1 緒㝘}

鋼の脱硫技術の進歩に伴い，鋼材の低硫化が指向され ており，硫黄含有率が $5 \mu \mathrm{g} \mathrm{g}^{-1}$ 以下の鋼も溶製される ようになった 。これに伴い，鋼中 $\mu \mathrm{g} \mathrm{g}^{-1}$ レベルの硫黄 の定量が要望されているが，一般に用いられている硫化

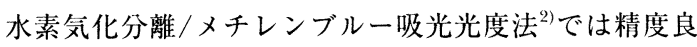
い定量值を得るには熟練を要し，燃燒赤外線吸収法 ${ }^{2} に$ 扔いては標準試料による補正が必要である，又，硫化水 素気化分離/メチレンブルー吸光光度法の高感度化のた めに, $2 \mathrm{~m}$ のキャピラリーセルを用いる方法 ${ }^{3)}$ や より モル吸光係数が大きなエチレンブルー吸光光度法を用い る方法 ${ }^{4)}$, 又溶媒抽出法によりメチレンブルーを濃縮す る方法”等が報告されているが，いずれの方法も煩雑で あるため, 精度良い定量值を得るには熟練を要する。

より簡便な方法として，鉄分離用のアルミナカラムを 用いたフローインジェクションー誘導結合プラズマ発光 分析法 (ICP-AES) ${ }^{6)}$ が報告されているが，共存元素の影 響を補正するために標準添加法の適用が必要である. 又, 硫黄の蒸留分離と測定が連続的に可能な気相試料導 入/ICP-AES ${ }^{7)}$ や，カソーディックストリッピングボル タンメトリー ${ }^{8}$ が適用されているが，いずれも鋼中 $\mu \mathrm{g}$ $\mathrm{g}^{-1}$ レベルの硫黄の定量には分析精度が不十分である.

これらの方法に対して，同位体希釈法は，標準試料に よる補正が不要であり, 試料前処理時に分析元素が一部 消失しても，定量値にほとんど影響がないため，精度良 い定量分析が期待できる。銓中の微量硫黄に対しても, 硫黄を $\mathrm{As}_{2} \mathrm{~S}_{3}$ 沈殿として回収した後，同位体希釈/熱イ オン化質量分析法により ${ }^{75} \mathrm{As}^{32} \mathrm{~S}^{+}$と ${ }^{75} \mathrm{As}^{34} \mathrm{~S}^{+}$を測定する 方法 ${ }^{9}$ が報告されている。 しかしこの方法では, 鋼中 $\mu \mathrm{g} \mathrm{g}^{-1}$ レベルの硫黄の定量には十分な分析精度が得ら れていない, 又, 同位体希䣋/ICP 質量分析法 (ICP-MS) に扔いて，主に水に起因する ${ }^{16} \mathrm{O}_{2}{ }^{+}$等のスペクトル干涉 を抑制するために加熱気化導入法が適用されている ${ }^{10)}$. この方法では, 試料溶液の畭燥後も黒鉛管に微量の水が 残存することから, ${ }^{16} \mathrm{O}_{2}{ }^{+}$によるバックグラウンドが高 く, 最も高感度な ${ }^{32} \mathrm{~S}^{+}$の測定ができないため, 鋼中 $\mu \mathrm{g}$ $\mathrm{g}^{-1}$ レベルの硫黄の定量を行うには濃縮操作が必要であ る.

そこで今回，同位体希釈/ICP-MS による鋼中の微量 硫黄の定量において, ${ }^{16} \mathrm{O}_{2}{ }^{+}$等の分子イオンによるバッ クグラウンドを低隇するために, 鋼中の硫黄を硫化水素 として蒸留分離した後, その硫化水素ガスを ICP-MS 装 置に導入する方法を試みたところ, 鋼中 $2 \mu \mathrm{g} \mathrm{g}^{-1}$ レべ ルの硫黄に対して $\pm 0.05 \mu \mathrm{g} \mathrm{g}^{-1}( \pm 1 \sigma)$, 相対標準偏差

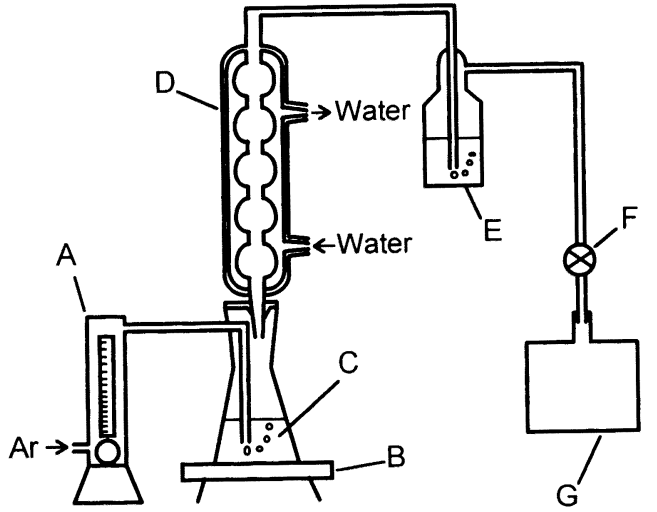

Fig. 1 Schematic diagram of apparatus for hydrogen sulfide evolution

A: gas flow meter; B: hot plate; C: sample solution; D: condenser; E: washing bottle; F: stopcock; G: sampling bag

$(\mathrm{RSD})=2.6 \%$ の精度で定量できることを確認したので, 以下に報告する。

\section{2 実験}

\section{$2 \cdot 1$ 装 置}

硫化水素の蒸留分離は, 硫化水素気化分離/メチレン ブルー吸光光度法 ${ }^{2}$ で使用される蒸留装置の硫化水素捕 集部を一部改良して行った．Fig. 1 に，硫化水素の蒸留 装置の模式図を示す．洗浄瓶（E）と二方コック（F） はシリコーンチューブによって接続し，二方コックはテ フロン製，硫化水素の捕集袋（G）はフッ化ビニル製の ものを使用した。

ICP-MS 装置は, VG-Elemental 製 Plasma Quad 2 plus を使用した. Fig. 2 に, 試料ガスの導入部を示す.ネブ ライザーとプラズマトーチは，パイレックス製のガラス 管により接続し，接続管とネブライザーはシリコーンチ ユーブにより固定した．測定時には，シリコーン製の二 方コックを開け，ネブライザーガスによる隇圧吸引力に より導入し，導入流量は流量計によって制御した。 Table 1 に，ICP-MS の測定条件を示す.

\section{$2 \cdot 2$ 試 薬}

硫黄標準溶液: $110^{\circ} \mathrm{C}$ で 2 時間乾燥した $\mathrm{K}_{2} \mathrm{SO}_{4} 5.4352$ $\mathrm{g}$ を水に溶解し, $1000 \mathrm{ml}$ に希釈し,この溶液を必要に 忍じ希釈して使用した。

${ }^{34} \mathrm{~S}$ 濃縮同位体溶液: ${ }^{34} \mathrm{~S}$ の濃縮同位体（硫黄単体, 


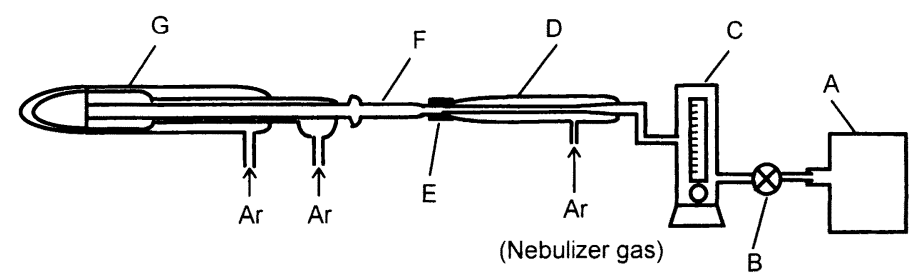

Fig. 2 Schematic diagram of sample gas introduction system for ICP-MS

A: sampling bag; B: stopcock; C: flow meter; D: nebulizer; E: silicone tube;

F: connector; $\mathrm{G}$ : plasma torch

Table 1 Instrumental operating conditions and data acquisition parameters

\begin{tabular}{lc}
\hline ICP mass spectrometer & \\
Rf power & $1200 \sim 1350 \mathrm{~W}$ \\
Outer gas flow rate & $141 \mathrm{~min}^{-1}$ \\
Auxiliary gas flow rate & $0.71 \mathrm{~min}^{-1}$ \\
Carrier gas flow rate & $0.65 \sim 1.051 \mathrm{~min}^{-1}$ \\
Sample gas flow rate & $20 \sim 401 \mathrm{~min}^{-1}$ \\
& \\
Data acquisition & \\
Measurement & scan mode \\
Number of channel & 512 \\
Number of scan & 1000 \\
Dwell time per channel & $80 \mu \mathrm{s}$ \\
Mass range & $1 \sim 60 \mathrm{~m} / \mathrm{z}$ \\
\hline
\end{tabular}

Oak Ridge National Laboratory 製) を硝酸 2, 塩酸 1, 臭素 $0.1 \mathrm{ml}$ に溶解した. $10 \%$ の $\mathrm{KOH}$ 溶液 $1 \mathrm{ml}$ を添加 して蒸発乾固した後, 水に溶解して $100 \mathrm{ml}$ に定容した. この溶液を使用の都度希釈して使用した。なお，この溶 液の硫黄濃度は, 硫化水素気化分離/エチレンブルー吸 光光度法及びイオンクロマトグラフ法によって求めた。 使用した ${ }^{34} \mathrm{~S}$ 濃縮同位体溶液の硫黄の同位体組成は, ${ }^{32} \mathrm{~S}: 5.53,{ }^{38} \mathrm{~S}: 0.11,{ }^{34} \mathrm{~S}: 94.33,{ }^{36} \mathrm{~S}: 0.03$ atom\% $\%$ ๖.

還元混液: ヨウ化水素酸（55\%）4 容と次亜リン酸 $(50 \%) 1$ 容を混合し，アルゴン（Ar）気流中で軽く沸 滕する程度に約 30 分間加熱精製した。

洗浄液: 塩酸 $(1+60) 3$ 容と塩酸ヒドラジン溶液・ $(5$ $\left.\mathrm{gl}^{-1}\right) 1$ 容を使用の都度混合し, 蒸留分離装置の洗浄瓶 に入れた。

鉄溶液: 純鉄（JSS 003-3） $1.00 \mathrm{~g}$ を塩酸 $40 \mathrm{ml}$ で加 热溶解し, 約 10 分間者沸した後, 硝酸 $5 \mathrm{ml}$ を少量ずつ 加えて Fe を酸化した，更に，煮沸して酸化窒素ガスを 避出した後, 水で $100 \mathrm{ml}$ に希釈した。
酢酸要鉛一酢酸ナトリウム吸収液: 酢酸覀鉛 (二水塩) $55 \mathrm{~g}$ と酢酸ナトリウム (三水塩) $14 \mathrm{~g}$ を水に溶解し, $1000 \mathrm{ml}$ に定容した。この原液を使用の都度水で 5 倍に 希釈して使用した.

硫酸第二鉄アンモニウム溶液: 硫酸第二鉄アンモニウ 厶 $\left(\mathrm{Fe}_{2}\left(\mathrm{SO}_{4}\right)_{3} \cdot\left(\mathrm{NH}_{4}\right)_{2} \mathrm{SO}_{4} \cdot 24 \mathrm{H}_{2} \mathrm{O}\right) 30 \mathrm{~g}$ を水に溶解し, $250 \mathrm{ml}$ とした.

$N, N$-ジメチル-p-フェニレンジアミン硫酸塩（DEPD） 溶液: DEPD $0.5 \mathrm{~g}$ を硫酸 $(3+17) 100 \mathrm{ml}$ に溶解した.

\section{$2 \cdot 3$ 分析操作}

$2 \cdot 3 \cdot 1$ 試料溶液の調製 鉄鋼試料と ${ }^{34} \mathrm{~S}$ 濃縮同位 体溶液を分解フラスコに採り, 王水 $20 \mathrm{ml}$ を加えて加熱 分解した後, $230^{\circ} \mathrm{C}$ に設定したホットプレート上で加熱 を続け, 乾固した. 次に塩酸 $20 \mathrm{ml}$ を加えて塩類を溶解 した後, 加熱乾固した. 塩酸添加の乾固操作を再度行っ た後，塩酸 $20 \mathrm{ml}$ を加え塩類を溶解した。なお，空試験 試料は, 鉄溶液 $1 \mathrm{ml}$ を添加して鉄鋼試料と同じ操作を 行うことにより調製した。

$2 \cdot 3 \cdot 2$ 硫化水素の蒸留分離試料溶液に還元混液 $30 \mathrm{ml}$ を加え 10 分間放置し, 更に還元混液 $5 \mathrm{ml}$ を添加 した後, 分解フラスコを蒸留装置に取り付け, 分解フラ スコの下にホットプレートを置いて加熱蒸留した。な お，事前に蒸留装置内の空気を追い出すために，5分間 以上 Ar による通気を行った。 又, 硫化水素の捕集袋は $\operatorname{Ar}$ の導入と排出を 5 回繰り返すことにより, 空気を追 い出した後使用した.

\section{$2 \cdot 4$ 同位体希釈法}

同位体希釈法を適用するために，質量差別効果 ${ }^{11)}$ の補 正を行った。鉄鋼標準試料（JSS 244-5，S：15 $\mu \mathrm{g} \mathrm{g}^{-1}$ ) に対して，濃縮同位体を添加せずに作製した試料ガスを 測定した場合，下式が成り立つ. 


$$
\frac{I_{34}-I_{34 \mathrm{~b}}}{I_{32}-I_{32 \mathrm{~b}}}=\alpha \frac{F_{34}}{F_{32}}
$$

式( 1 ) において， $I_{32} ， I_{34}$ は質量数 $32 ， 34$ における 各測定強度， $I_{32 \mathrm{~b}} ， I_{34 \mathrm{~b}}$ は質量数 32,34 における各バッ クグラウンド強度， $F_{32}, F_{34}$ は自然界における ${ }^{32} \mathrm{~S},{ }^{34} \mathrm{~S}$ の各同位体存在比であり $\left(F_{32}: 95.02, F_{34}: 4.22\right.$ atom\%), $\alpha$ は質量差別効果の補正係数である. なお， $\alpha$ の実測値 は 0.9〜1.0（日間変動）の範囲にあった。

硫黄は自然界において同位体存在比が変化する元素で

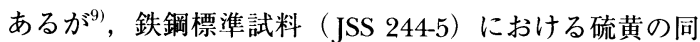
位体存在比は, 標準試料（ZnS, NIST SRM8556）との 比較から, 自然界の同位体存在比とほほ一致することを 確認した。

次に, 式(1) で求めた $\alpha$ を式（2）に代入し, 試料 ガス中硫黄の含有量 $X(\mathrm{~mol})$ を求め, 鋼中含有率 $(\mu \mathrm{g}$ $\left.\mathrm{g}^{-1}\right)$ に換算した。

$$
\frac{I_{34}-I_{34 \mathrm{~b}}}{I_{32}-I_{32 \mathrm{~b}}}=\frac{X F_{34}+Y F_{34}^{\prime}+Z F_{34}}{X F_{32}+Y F_{32}^{\prime}+Z F_{32}}
$$

式（２）において，Yは濃縮同位体の添加量 (mol), $F_{32}^{\prime}, \quad F_{34}^{\prime}$ は濃縮同位体中の ${ }^{32} \mathrm{~S},{ }^{34} \mathrm{~S}$ の各同位体存在比 $\left(F_{32}^{\prime}: 5.53, F_{34}^{\prime}: 94.33\right.$ atom\%)，Zは空試験值 $(\mathrm{mol})$ である.なお $Z$ の值は， $X$ の值が既知の鉄鋼標準試料 （JSS 003-3）について，あらかじめ $2 \cdot 3$ に示した方法に 従って作製した試料ガスを用いて求めた。

\section{3 結果と考察}

\section{$3 \cdot 1$ 硫化水素の蒸留分離の条件}

同位体希釈法を適用する場合，試料ガスを完全に回収 する必要がないが, 不十分であると測定上の感度が低下 する. そこで硫化水素の蒸留分離条件を決めるために， 硫化水素の回収に対する蒸留温度, Ar キャリヤーガス 流量の影響について調査した。

$3 \cdot 1 \cdot 1$ 蒸留温度の影響 今回, 硫化水素の最適な 蒸留時間を検討するために, 蒸留時に発生する硫化水素 を一定時間ごとに回収する方法を適用した。なお，捕集 袋を用いて試料ガスを回収する場合，一定時間ごとに捕 集袋を取り替えるのは困難であったため，硫化水素気化 分離/エチレンブルー法 ${ }^{4}$ におおける酢酸覀鉛-酢酸ナトリ ウム吸収液に硫化水素を捕集した後，DEPD 溶液を用い て発色させることにより，硫黄の回収量の時間変化を調 査した。 Fig. 3 に，蒸留温度を $200 ， 250 ， 300^{\circ} \mathrm{C}$ に設 定した場合の蒸留時間と吸光度の関係を示す。純鉄

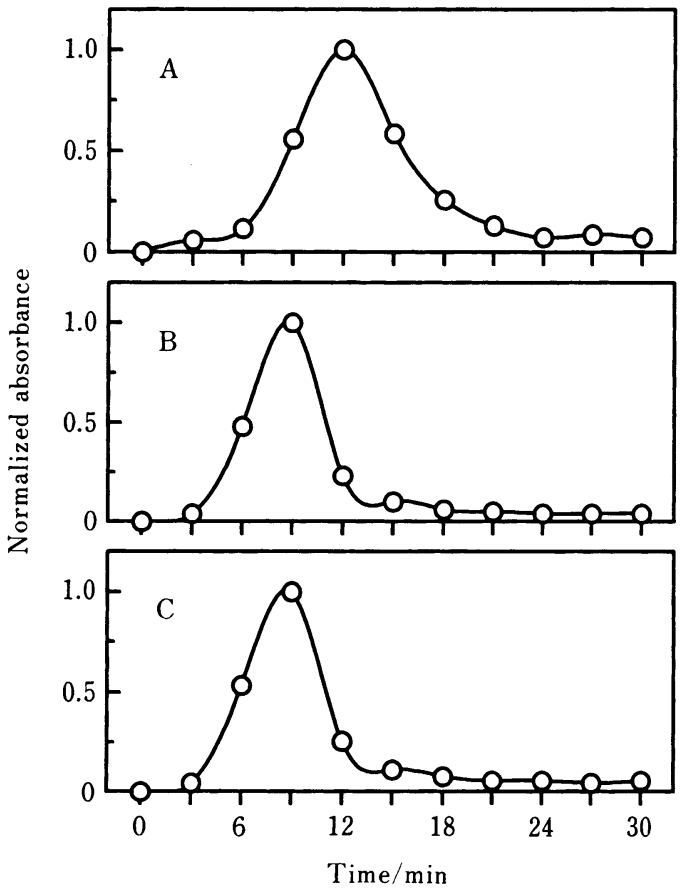

Fig. 3 Effect of distillation temperature on the normalized absorbance of ethylene blue

Distillation temperature: 200 ( A ), 250 ( B ), $300^{\circ} \mathrm{C}$ $(\mathrm{C})$; Argon carrier gas flow rate: $100 \mathrm{ml} \mathrm{min}^{-1}$; Mass of sulfur: $20 \mu \mathrm{g}$; Mass of iron: $0.01 \mathrm{~g}$

$0.01 \mathrm{~g}$ に硫黄 $20 \mu \mathrm{g}$ を添加した試料を，2·3・1 で示した 操作に従って調製した試料溶液に対して，蒸留開始から 3 分ごとに吸収液を交換し，各吸収液を発色後，エチレ ンブルー吸光光度法により吸光度を測定した。なお， Fig. 3 における吸光度は各温度条件において最も高い吸 光度を示した試料溶液の吸光度を 1 として規格化した

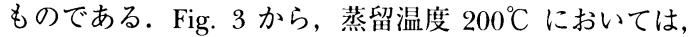
$250^{\circ} \mathrm{C}$ あるいは $300^{\circ} \mathrm{C}$ と比較して，蒸留開始時間及び終 了時間が若干遅くなるのに対し， $250^{\circ} \mathrm{C}$ 以上では蒸留開 始 3 分後に硫化水素の蒸留は開始し，23 分後にはほほ 終了することが分かった。従って蒸留温度は $250^{\circ} \mathrm{C} に$ 設定することにした。

3・1・2 Ar キャリヤーガス流量の設定 Fig. 4 に， Fig. 3 と同様の方法に従って調製した試料溶液に関し て， Arキャリヤーガス流量を $50,100,150 \mathrm{ml} \mathrm{min}^{-1}$ に設定した場合の蒸留時間と吸光度の関係を示す. Fig. 4 から, 各ガス流量において, 蒸留開始 3 分後に硫化水 素の蒸留は開始し，23 分後にはほぼ終了することが分 かった．なお，試料ガス中の硫黄を高濃度にするために 


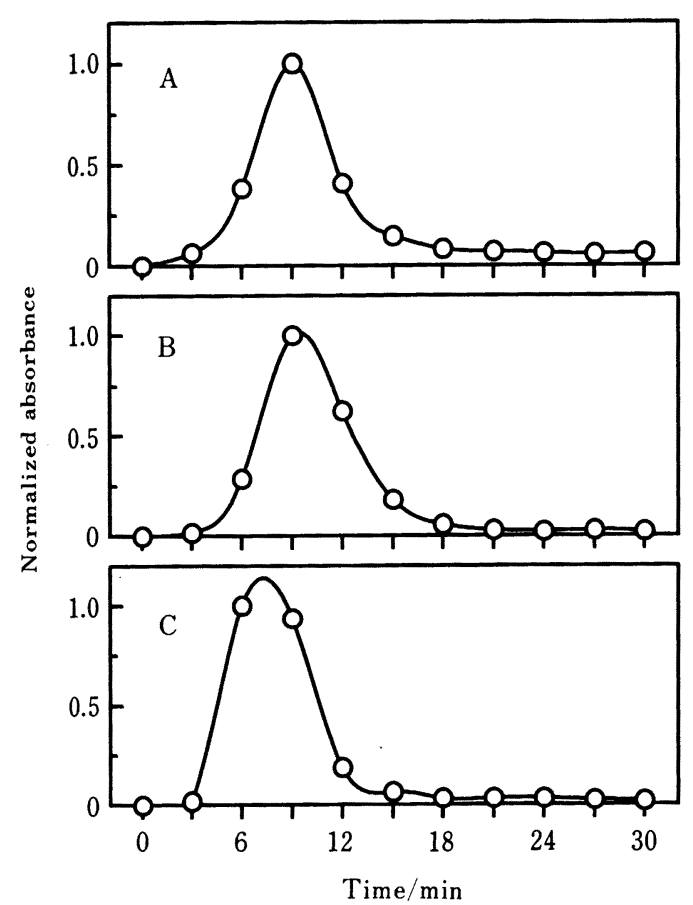

Fig. 4 Effect of argon carrier gas flow rate on the normalized absorbance of ethylene blue

Argon carrier gas flow rate: 50 ( A ), 100 ( B ), 150 $\mathrm{ml} \mathrm{min}{ }^{-1}$ ( C ) ; Distillation temperature: $250^{\circ} \mathrm{C}$; Mass of sulfur: $20 \mu \mathrm{g}$; Mass of iron: $0.01 \mathrm{~g}$

は, $\mathrm{Ar}$ キャリヤーガス流量は極力下げたほうが有利で あるが，測定上試料ガス量が不足する場合があったた

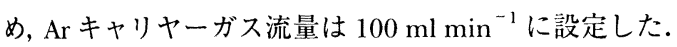
Fig. 3 と 4 は, 鉄量 $0.01 \mathrm{~g}$, 硫黄量 $20 \mu \mathrm{g}$ に関する結果 であるが, 鉄量 $0.01 \sim 2.0 \mathrm{~g}$, 硫黄量 5〜20 $\mu \mathrm{g}$ に対して も, 蒸留開始 3 分後に硫化水素の蒸留は開始し, 23 分 後にほぼ終了することを確認した，以上の検討により， 試料ガスは蒸留開始後 3 分以降 23 分までの 20 分間捕 集することにした。

\section{$3 \cdot 2$ 測定条件の検討}

同位体希釈法においては, 同位体の強度比の変動が分 析精度に大きく影響する。 そこで今回, ${ }^{32} \mathrm{~S}^{+}$と ${ }^{34} \mathrm{~S}^{+}$の 強度比に対するネブライザーガス流量, 高周波（rf）パ ワー及び試料ガス流量の影響について検討した。

3・2・1 ネブライザーガス流量の影響 Fig. 5 に, 質量数 32,34 の強度（バックグラウンド強度差し引き 分) 及び質量数 32,34 の強度比と, ネブライザーガス

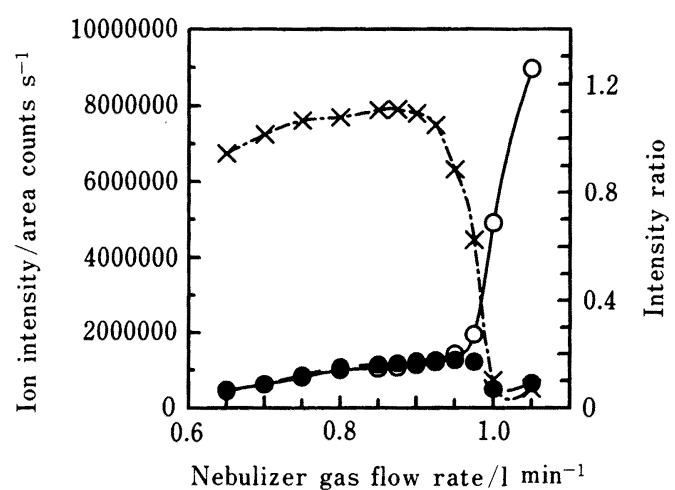

Fig. 5 Effect of nebulizer gas flow rate on the ion intensity at mass 32 and 34 , and the intensity ratio of ${ }^{34} \mathrm{~S}^{+}$to ${ }^{39} \mathrm{~S}^{+}$

$\bigcirc: I_{32}-I_{32 \mathrm{~b}} ; I_{34}-I_{34 \mathrm{~b}} ; \times:\left(I_{34}-I_{34 \mathrm{~b}}\right) /\left(I_{32}-I_{32 \mathrm{~b}}\right)$; Sample: $2 \mathrm{~g}$ of JSS 244-5 (S, $\left.15 \mu \mathrm{g} \mathrm{g}^{-1}\right)+$ spike (S, $35.18 \mu \mathrm{g})$; Rf power: $1350 \mathrm{~W}$; Sample gas flow rate: $30 \mathrm{ml} \mathrm{min}^{-1}$

流量の関係を示す。試料ガスは, 鉄鋼標準試料（JSS 244-5） $2.0 \mathrm{~g}$ に対して ${ }^{34} \mathrm{~S}$ の濃縮同位体を $35.18 \mu \mathrm{g}$ 添加 した後, $2 \cdot 3 \cdot 1$ と $2 \cdot 3 \cdot 2$ に示した方法に従って調製した. 又, バックグラウンド強度は, Arを導入し, 試料ガス と同様の条件に従って測定した. Fig. 5 から, 質量数 32 と 34 の強度は, $0.951 \mathrm{~min}^{-1}$ 以下ではネブライザー ガス流量が増すにつれて徐々に増加するのに対し， 0.95 $1 \mathrm{~min}^{-1}$ 以上では質量数 32 の強度は急激に増大し, 質 量数 34 の強度は若干減少することが分かった，又，質 量数 32 と 34 の強度比は, ネブライザーガス流量が 0.85〜0.901 min -1 の範囲でほぼ一定となり，0.951 $\min ^{-1}$ 以上で急激に減少することが分かった，従って， ネブライザーガス流量は $0.881 \mathrm{~min}^{-1}$ に設定することに した。なお， $0.951 \mathrm{~min}^{-1}$ 以上で質量数 32 の強度のみ が大幅に増大することから，質量数 32 の強度の急激な 増加は ${ }^{16} \mathrm{O}_{2}{ }^{+}$が影響していると考えられる．通常の水溶 液噴霧法においては，ネブライザーガス流量の増加に伴 い, 単位時間当たりの試料導入量が増し, 分析元素イオ ンの測定強度は増加するが, 水の導入量がある一定以上 になるとプラズマ温度が下がり, 測定強度は減少する. 一方, 今回のガス導入法では水の影響はなく, 試料ガス 流量は一定に制御されているため，ネブライザーガス流 量が増えても単位時間当たりの硫化水素の導入量は一定 である。従って，今回見られたネブライザーガス流量に 伴う測定強度の変化は, Ar の導入量によりプラズマ状 態が変わり, 硫黄あるいは酸素分子のイオンの生成量に 
違いが生じたためと考えられる。

3.2.2 rf パワーの影響 Fig. 6 に, 質量数 32,34 の強度及び強度比と $\mathrm{rf}$ パワーの関係を示す。なお, 試 料ガスは Fig. 5 と同様の方法で調製した. Fig. 6 から, 質量数 32 の強度は rf パワーの增大とともに減少し, 質 量数 34 のバックグラウンド強度は低いレベルでほほ一 定であることが分かった．質量数 32 のバックグラウン ド強度も rf パワーの増加とともに隇少することから, rf パワーが増すとプラズマ温度は上昇し, 酸素分子の解離 が促進されるため, ${ }^{16} \mathrm{O}_{2}{ }^{+}$の強度が減少したと考えられ る.一方，バックグラウンド強度を差し引いた後の質量 数 32 と 34 の強度比はほほ一定であったが, 質量数 32 のバックグラウンド強度を減少させるためには, rf パワ 一をより高值に設定する必要があったため, rf パワーは 1350 Wに設定することにした。

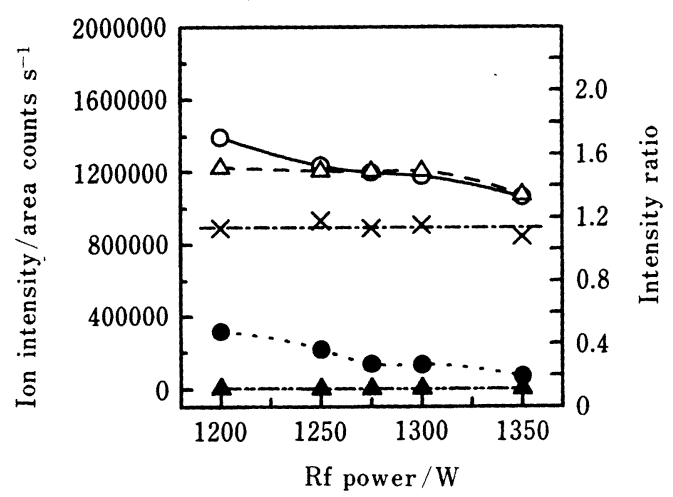

Fig. 6 Effect of $\mathrm{rf}$ power on the ion intensity at mass 32 and 34 , and the intensity ratio of ${ }^{34} \mathrm{~S}^{+}$to ${ }^{32} \mathrm{~S}^{+}$

$\bigcirc: I_{32} ; \Delta: I_{34} ;: I_{32 \mathrm{~b}} ; \Delta: I_{34 \mathrm{~b}} ; \times:\left(I_{34}-I_{34 \mathrm{~b}}\right) /($ $\left.I_{32}-I_{32 \mathrm{~b}}\right)$; Sample: $2 \mathrm{~g}$ of JSS $244-5\left(\mathrm{~S}, 15 \mu \mathrm{g} \mathrm{g}^{-1}\right)+$ spike $(\mathrm{S}, 35.18 \mu \mathrm{g})$; Nebulizer gas flow rate: $0.88 \mathrm{ml}$ $\min ^{-1}$; Sample gas flow rate: $30 \mathrm{ml} \mathrm{min}^{-1}$ $\mathbf{3 \cdot 2 \cdot 3}$ 試料ガス流量の影響 Fig. 7 に, 質量数 32, 34 における強度及び強度比と試料ガス流量の影響を示 す.なお，試料ガスは Fig. 5 と同様の方法に基づき調 製した. Fig. 7 から, 試料ガス流量の増加に伴い質量数 32 と 34 の強度は増大するのに対し, 強度比はほほ一定 であることが分かった.より高感度な測定を行うために は，試料ガス流量を高く設定したほうが有利であるが， 試料ガス量の消費を抑制するために，試料ガス流量は $30 \mathrm{ml} \mathrm{min}{ }^{-1}$ に設定することにした.

\section{4 定量 結果}

今回確立した定量法を，日本鉄鋼協会認証の鉄鋼標涑 試料及び実試料として高純度鉄中の硫黄の定量に適用し た. Table 2 に, JSS 003-3 (高純度鉄), JSS 244-5 (硫 黄専用鋼）と実試料の定量結果を示す。なお比較のため

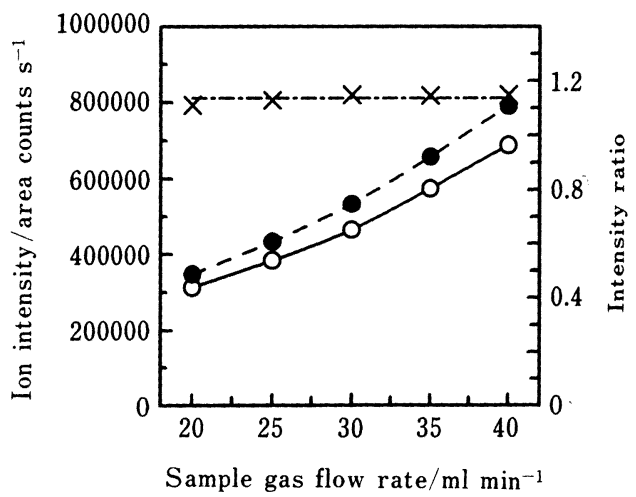

Fig. 7 Effect of sample gas flow rate on the ion intensity at mass 32 and 34 , and the intensity ratio of ${ }^{34} \mathrm{~S}^{+}$to ${ }^{32} \mathrm{~S}^{+}$

$\bigcirc: I_{32}-I_{32 \mathrm{~b}} ; I_{34}-I_{34} \mathrm{~b} ; \times:\left(I_{34}-I_{34} \mathrm{~b}\right) /\left(I_{32}-I_{32 \mathrm{~b}}\right)$; Sample: $2 \mathrm{~g}$ of JSS 244-5 (S, $\left.15 \mu \mathrm{g} \mathrm{g}^{-1}\right)+$ spike (S, $35.18 \mu \mathrm{g})$; Nebulizer gas flow rate: $0.88 \mathrm{ml} \mathrm{min}^{-1}$; Rf power: $1350 \mathrm{~W}$

Table 2 The determination of sulfur in JSS CRMs and a high-purity iron sample

\begin{tabular}{lccc}
\hline \multirow{2}{*}{ Sample } & \multicolumn{3}{c}{ Sulfur content $/ \mu \mathrm{g} \mathrm{g}^{-1}$} \\
\cline { 2 - 4 } & Certified values & This work $^{\mathrm{a})}$ & Other methods $^{\mathrm{a})}$ \\
\hline JSS 003-3 & $1.9^{\mathrm{b})}$ & $1.94 \pm 0.05(2.6)^{\mathrm{c}}$ & $2.01 \pm 0.06^{\mathrm{d})}(3.0)^{\mathrm{c})}$ \\
JSS 244-5 & 15 & $15.04 \pm 0.13(0.9)^{\mathrm{c})}$ & $\overline{-}^{\mathrm{c}}$ \\
Sample A & - & $3.38 \pm 0.10(3.0)^{\mathrm{c}}$ & $3.19 \pm 0.15^{\mathrm{c})}(4.7)^{\mathrm{c})}$ \\
\hline
\end{tabular}

a) Mean $\pm 1 \times$ (standard deviation) from five determinations, b) Reference value, c) \% Relative standard deviation, d) Infrared absorption of $\mathrm{SO}_{2}$ following combustion in an induction furnace (Leco CS444LS), e) Ethylene blue spectrophotometric method after $\mathrm{H}_{2} \mathrm{~S}$ evolution. 
に, JSS 244-5 については認証值, JSS 003-3 は参考值と 燃焼赤外線吸収法による定量值, 実試料に関しては硫化 水素気化分離/エチレンブルー吸光光度法及び燃焼赤外 線吸収法による定量值を併せて示した。

Table 2 から, 本定量法による定量值は認証值及び他 法による定量值とほぼ一致することが分かった。 又, 鋼 中 $2 \mu \mathrm{g} \mathrm{g}^{-1}$ の硫黄に対して, $\pm 0.05 \mu \mathrm{g} \mathrm{g}^{-1}( \pm 1 \sigma)$, $\mathrm{RSD}=2.6 \%$ の精度で定量できることが判明した。更に, $0.01 \mathrm{~g}$ の高純度鉄（JSS 003-3）を用いて作製した試料 ガスを空試験值として, 测定強度の標準偏差の 3 倍を 検出限界とした場合, 本定量法の検出限界は $0.2 \mu \mathrm{g} \mathrm{g}^{-1}$ となった.

\section{文献}

1) 雀部 実: 第 $143 \cdot 144$ 回西山記念技術講座, p. 3 (1992).
2) JIS G 1215, 鉄及び鋼一硫黄定量方法 (1994).

3) K. Chiba, I. Inamoto, K. Tsunoda, H. Akaiwa: Analyst (London), 119, 709 (1994).

4) S. Hinotani, J. Endo, T. Takayama, N. Mizui, Y. Inokuma: ISIJ Int., 34, 17 (1994).

5) 成田貴一, 谷口政行, 太田法明, 諸岡錬平: 鉄 と鋼, 67, 2724 (1981).

6) K. Yamada, C. W. Mcleod, O. Kujirai, H. Okochi : J. Anal. At. Spectrom., 7, 661 (1992).

7) 戸田英二, 久保田剛包, 市川五朗: 分析化学 (Bunseki Kagaku), 41, 453 (1992).

8) 石山高, 広門孝男, 田中龍彦: 分析化学 (Bunseki Kagaku), 46, 287 (1997).

9) W. R. Kelly, L.-T. Chen, J. W. Gramlich, K. E. Hehn: Analyst (London), 115, 1019 (1990).

10) H. Naka, D. C. Grégoire: J. Anal. At. Spectrom., 11, 359 (1996).

11) 要野浩一, 一八瀬達也, 古田直紀: 第 58 回分析 化学討論会講演要旨集, p. 75 (1997).

\section{要 旨}

硫化水素気化分離/同位体希釈/ICP-MSによる䤡中の微量硫黄の定量法を確立した。試料溶液の蒸留 によって発生した硫化水素を捕集し，その硫化水素ガスを ICP-MS 装置に導入する方法を適用した. 硫 化水素の蒸留時間を決めるために, 蒸留温度, Ar キャリヤーガス流量の影響を調査したところ, 各々 $250^{\circ} \mathrm{C}, 100 \mathrm{ml} \mathrm{min}{ }^{-1}$ に設定した場合, 約 20 分間の蒸留時間で硫黄はほぼ完全に回収できることを確認 した. ICP-MSにおいて, ${ }^{32} \mathrm{~S}^{+} と{ }^{34} \mathrm{~S}^{+}$の強度比及び各強度に対する, ネブライザーガス流量, rf パワー, 試料ガス流量の影響を調べたところ, 各々 $0.881 \mathrm{~min}^{-1}, 1350 \mathrm{~W}, 30 \mathrm{ml} \mathrm{min}^{-1}$ に設定した場合, ${ }^{39} \mathrm{~S}^{+}$ と ${ }^{34} \mathrm{~S}^{+}$の強度比がほぼ一定となり, ${ }^{39} \mathrm{~S}^{+},{ }^{34} \mathrm{~S}^{+}$におけるバックグラウンド強度はより小さくなることを 確認した. 確立した定量法の検出限界 $(3 \sigma)$ は $0.2 \mu \mathrm{g} \mathrm{g}^{-1}$ であり, 日本鉄鋼協会認証の鉄鋼標準試料や 実際の高純度鉄中の硫黄の定量に適用したところ, 得られた定量值は, 鋼中 $2 \mu \mathrm{g} \mathrm{g}^{-1} レ$ レルの硫黄に対 して，RSD=2.6\%の精度で定量できることを確認した. 